Southeast Asian Journal of Islamic Education Management

Vol. 1 No. 2 (2020),pp 221-235

http://sajiem.iainponorogo.ac.id/sajiem
p-ISSN: 2716-0599

e-ISSN: 2715-9604

\title{
Kepemimpinan inovatif dalam pengembangan organisasi dan team
}

Jaudi

Institut Agama Islam Darullughah Waddda'wah Bangil Pasuruan, Indonesia

Jaudipontianak@gmai.com

DOI: https://doi.org/10.21154/sajiem.vii2.35

\begin{tabular}{|l|l|l}
\hline Received:oomonth 2019 & Revised: oomonth 2019 & Approved:oomonth 2019
\end{tabular}

\begin{abstract}
Abstrak
Artikel ini menyajikan tentang organisasi senantiasa mengalami perubahan karena faktor pendorong baik yang berasal dari dalam organisai maupun luar organisasi. Saat ini, agar suatu organisasi mampu bertahan tidak cukup hanya mengandalkan kharisma seorang pemimpin, maka diperlukan pula kecerdasan dari seorang pemimpin untuk merespon berbagai perubahan yang terjadi disekitarnya serta melakukan berbagai macam inovasi, baik itu melaui Organizational Development (OD), Team Building maupun Pengembangan Individu untuk membentuk perilaku innovative. Metodologi atau Pendekatan yang digunakan dalam tulisan ini menggunakan metode atau pendekatan library research, sedangkan pengumpulan data dilakukan dengan menelaah beberapa buku, jurnal baik yang berbentuk cetak maupun elektronik serta sumber-sumber data dan atau informasi lainnya yang dianggap relevan dengan kajian. Temuan dalam kajian ini kinerja adalah dalam diri manusia terdapat kecerdasan spiritual (spiritual quotient SQ), sebagai salah satu model kepemimpinan yang perlu diadopsi dan mendapat tanggapan dari seorang pemimpin yakni model kepemimpinan spiritual. Dalam melakukan pengembangan organisasi hendaknya memperhatikan faktor komunikasi baik tentang program, proses maupun monitoring dan evaluasi), sosiologis, psikologis dan historis yang melingkupi organisasi sehingga pada saat seorang pemimpin melakukan perubahan tidak akan terjadi gejolak yang besar diantara para anggota organisasi.
\end{abstract}

Kata Kunci: Kepemimpinan inovatif, organisasi.

\section{Pendahuluan}

Pluralisme merupakan realitas hidup dalam masyarakat modern. Bermacam kelompok sosial, organisasi, badan pemerintah, perkumpulan, gerakan-gerakan sosial, partai politik, lembaga kemasyarakatan, termasuk didalamnya lembaga pendidikan dan lain sebagainya. 
Masing-masing organisasi atau kelompok mempunyai interest, tujuan dan daerah operasi sendirisendiri. Maka persaingan, kompetisi dan konflik merupakan realitas nyata yang banyak terjadi di tengah masyarakat modern. ${ }^{1}$ Realitas inilah yang menyebabkan adanya keniscayaan bagi suatu organisasi yang ingin tetap survive ditengah masyarakat untuk selalu merespon perkembangan yang ada, baik yang berasal dari luar organisasi maupun yang berasal dari tuntutan anggotanya, agar tidak tertinggal dari organisasi lain, atau bahkan akan "gulung tikar" meski ia telah memiliki sejarah yang panjang.

Hal ini senada dengan apa yang dikemukakan oleh Warrent Bennis sebagaimana berikut: ${ }^{2}$

"Bila perubahan dalam sistem nilai akan berkelanjutan, maka setiap organisasi harus berusaha belajar untuk lebih responsif, baik terhadap lingkungannya maupun terhadap tuntutan para anggotanya”.

Saat ini kemampuan bertahan suatu organisasi bukan hanya ditentukan dengan mengandalkan kharisma pemimpin saja, akan tetapi juga kemampuan dari seorang pemimpin untuk merespon segala yang ada dan terjadi disekitarnya serta memiliki good will untuk selalu melakukan pengembangan organisasinya. Dalam hal ini seorang pemimpin hendaknya memiliki kecerdasan yang tinggi dalam merespon lingkungannya, karena seorang pemimpin tidak berdiri sendiri dalam memimpin sebuah organisasi melainkan ia terkait dengan situasi (situation) termasuk didalamnya tugas, tekanan, lingkungan, dan lain sebagainya serta pengikut (followers) yang didalamnya terdapat norma-norma, nilai-nilai, keterpaduan, dll. ${ }^{3}$ Teori modern memandang suatu organisasi sebagai suatu sistem yang terdiri dari lima bagian pokok, yaitu input, proses output (arus balik) dan lingkungan. ${ }^{4}$ Sebagaimana Sondang P. Siagian menyebutkan bahwa Kepemimpinan tidak pernah bergerak dan berfungsi suasana vakum. Ia bersifat situasional, kondisional, temporal dan spatial, atau dengan kata lain banyak faktor yang mempengaruhi efektivitas kepemimpinan seseorang. ${ }^{5}$

\footnotetext{
1 Kartini Kartono. 2004. Pemimpin dan Kepemimpinan, Apakah Pemimpin Abnormal itu?. Jakarta; RajaGrafindo Persada. Cet. 12 hlm. 243

${ }^{2}$ Adam I. Indrawijaya. 1989. Perubahan dan Pengembangan Organisasi, Bandung; Penerbit Sinar Baru. Hlm. 17

${ }^{3}$ Hughes, Ginnet and Curphy. 2002. Leadership; Enhancing The Lesson of Experience 4thEd. McGraw Hill Irwin. Hlm. 24

${ }^{4}$ Dicky Wisnu Ur-Siti Nurhasanah. 2005. Teori Organisasi, Struktur dan Desain . Malang; UMM Press. Cetakan kedua. Hlm. 117

${ }^{5}$ Sondang P. Siagian. 1987. Teknik Menumbuhkan Dan Mengembangkan Perilaku Organisasional. Jakarta; CV Haji Masagung. Cet. 1 hlm. 81
} 
Analisa Adam I. Indrawijaya faktor pendorong pemimpin untuk senantiasa merespon lingkungan sekitar diantaranya ${ }^{6}$

Pertama, Kompleksitas hubungan kerja internal maupun antar organisasi dalam hal ini pemimpin perlu bekerjasama dengan organisasi lain. Seorang pemimpin harus memiliki kesadaran yang tinggi bahwa ia dan organisasinya "tidak sendiri", artinya Organisasi yang dipimpinnya berada ditengah organisasi lain baik yang sejenis maupun tidak sehingga suatu keharusan bagi suatu organisasi untuk bekerjasama dengan organisasi lain.

Kedua, Dengan semakin banyaknya penggunaan teknologi dalam organisasi, maka Seorang pemimpin dituntut melakukan hubungan manusiawi dengan anggota organisasinya. Seringkali terlupakan oleh para pemimpin organisasi bahwa yang mereka pimpin adalah manusia bukan robot, sehingga pola interaksi yang dilakukan seringkali bersifat "kaku", kurang manusiawi serta kurang memperhatikan dan menghargai potensi yang dimiliki oleh masing-masing anggota organisasi. Sebagai manusia (anggota organisasi) menuntut untuk diperlakukan secara manusiawi misalnya usaha yang dilakukannya dihargai, perannya dalam organisasi diakui, diberi kesempatan untuk mengembangkan potensi yang ia miliki, tercukupi kebutuhan dan kesejahteraannya dan lain sebagainya. Intinya seorang pemimpin harus mampu "memanusiakan manusia".

\section{Pengembangan Organisasi (Organizational Development/OD)}

Organisasi dapat bertahan survive terhadap lingkungan yang selalu berubah, bila berusaha untuk meningkatkan efisiensi dan efektivitasnya. Dari aspek manajemen, upaya untuk meningkatkan keberhasilan organisasi dalam menjawab perubahan lingkungan tersebut di antaranya dengan melakukan pengembangan organisasi. ${ }^{7}$

Istilah Organizational Development (OD/ Pengembangan Organisasi) mulai dikenal pada tahun 1960-an ${ }^{8}$. Organizational Development (OD) menurut Newstorm dan Davis (1997) dalam Husaini Usman ${ }^{9}$ adalah Strategi intervensi yang memanfaatkan proses kelompok untuk berfokus pada budaya organisasi secara menyeluruh dalam rangka melakukan perubahan yang diinginkan.

\footnotetext{
${ }^{6}$ Adam. I. Indrawijaya. Loc. Cit. Hlm. 17-19

${ }_{8}^{7}$ www.depdiknas.go.id/Jurnal/41 Subijanto.htm-83k

${ }^{8}$ George Strauss dan Leonard R. Sayles. 1980. Manajemen Personalia-Segi Manusia dalam Organisasi. Alih Bahasa Oleh Grace M Hadikusuma-Rochmulyati Hamzah. 1991. Jakarta; Gramedia. Cet. 2 edisi Revisi. hlm. 302

${ }^{9}$ Husaini Usman. 2004. Manajemen Pendidikan. Yogyakarta; Universitas Negeri Yogyakarta. Hlm. 206
} 
OD diperlukan karena pertama, struktur imbalan tidak cukup memperkuat pelatihan konvensional dan kedua laju perubahan yang berlangsung cepat. ${ }^{10}$

Dalam Freud Luthans ${ }^{11}$, Warrent Bennis ${ }^{12}$ dan Richard Beckhart ${ }^{13}$ mengatakan: Organizational Development (OD) adalah pendekatan modern, terencana dalam memberdayakan SDM yang dimiliki. Ditarik kesimpulan OD merupakan usaha tererncana organisasi dalam menjawab segala tantangan, perubahan dan tuntutan iternal dan eksternal serta fokus memanfaatkan potensi yang dimiliki.

Usaha Wendell French dalam pemecahan masalah melalui manajemen budaya Organisasi diantaranya: Pertama, melakukan analisis SWOT (Strenght, Weakness, Opportunity and Treat) terhadap setiap elemen organisasi. Kedua, meningkatkan efektifitas dan efisiensi kinerja anggota organisasi. Ketiga, Manajemen kolaboratif melalui partisipasi bawahan dan pembagian kekuasaan. Keempat, perlu dikembangkan rasa saling terbuka, percaya, kerjasama, persaingan. Kelima, kegiatan perlu didahului riset tentang kelebihan, kelemahan, peluang dan hambatan yang akan dihadapi dalam pelaksanaan kegiatan.

Husaini Usman mengidentifikasi Indikator organisasi bermutu diantaranya: 1) berfokus pada pelanggan, 2) berfokus pada pencegahan masalah, 3) investasi pada manusia dan menganggap manusia sebagai aset organisasi yang tak ternilai, 4) memiliki strategi untuk mencapai mutu, 5) memperlakukan keluhan sebagai umpan balik untuk memperbaiki diri (responsif), 6) memiliki kebijakan dalam perencanaan mutu, 7) mengupayakan proses perbaikan terus-menerus dengan melibatkan semua terkait (partisipatif), 8) membentuk fasilitator)yang bermutu (mau dan mampu memimpin proses perbaikan), 9) mendorong orang yang untuk berinovasi dan berkreasi, 10) memperjelas peranan dan tanggung jawab setiap orang , 11) memiliki strategi evaluasi yang obyektif dan jelas, 12) memiliki rangka jangka panjang, 13) memiliki rencana jangka panjang, visi dan misi , 14) memandang mutu sebagai bagian dari kebudayaan, 15) terbuka dan bertanggung jawab. ${ }^{14}$

\footnotetext{
${ }^{10}$ Keith Davis. 1985. Human Behavoir at Work: Organizational Behavior, Seventh Edition. Alih bahasa oleh Agus dharma. 2004. Jakarta; Erlangga. Cet. $12 \mathrm{Hlm} .246$

${ }^{11}$ Hadari Nawawi. 2003. Kepemimpinan Mengefektifkan Organisasi. Yogyakarta; Gadjah Mada University Press. Hlm. 196

${ }^{12}$ Adam I. Indrawijaya. Op. Cit. Hlm. 37

${ }^{13}$ Ibid. Hlm. 37-38

${ }^{14}$ Husaini Usman. Loc. Cit hlm. 211
} 
Adapun kelebihan dan kekurangan OD menurut Newstrom dan Davis, 1997 diantaranya adalah: ${ }^{15}$

\begin{tabular}{|c|c|}
\hline Kelebihan & Kekurangan \\
\hline 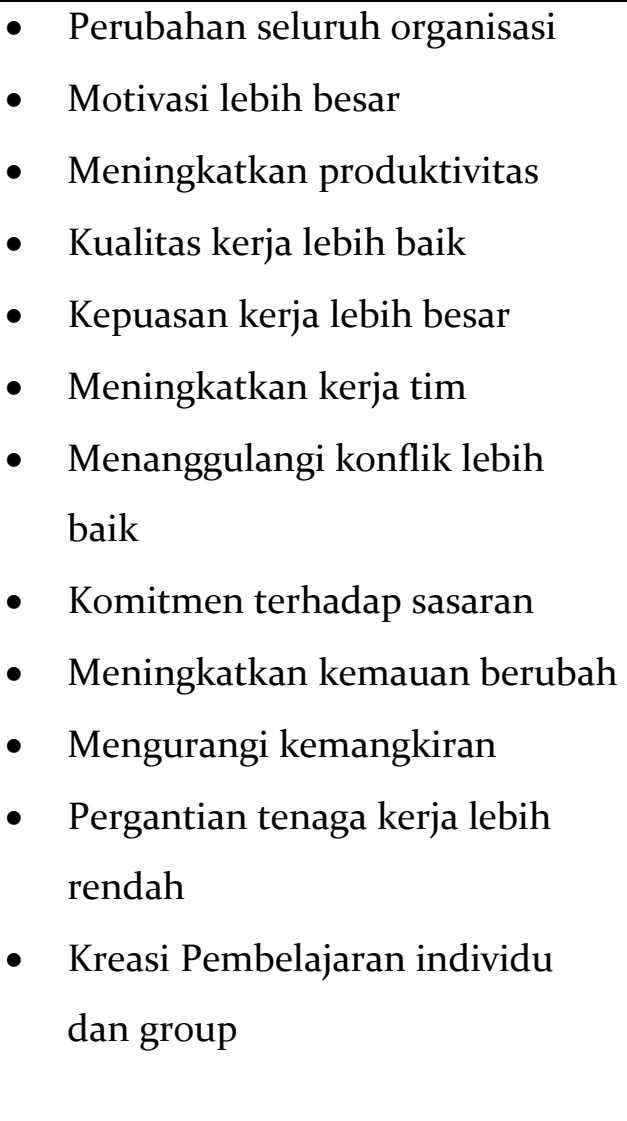 & $\begin{array}{l}\text { - } \text { Diperlukan banyak waktu } \\
\text { - } \text { Biaya besar } \\
\text { - } \text { genunda periode pembayaran } \\
\text { - } \text { Kemungkinan gagal } \\
\text { - } \text { Kemungkiann invasi privasi } \\
\text { - } \text { Kemungkian gangguan } \\
\text { - } \text { psikologi } \\
\text { - } \text { Kemungkinan timbul } \\
\text { - } \text { Kempormitas } \\
\text { - } \text { Suripada kinerja } \\
\text { - } \text { Bertentangan dengan budaya }\end{array}$ \\
\hline
\end{tabular}

Mengatasi sumber daya yang dibangun (kelompok-kelompok dalam organisasi yang mengendalikan sumber daya tertentu seringkali melihat perubahan sebagai suatu ancaman, sehingga mereka cenderung merasa puas dengan cara berpikir mereka sendiri), ${ }^{16}$ antara lain adalah:

1) Pendidikan dan komunikasi (agar tercapai persamaan persepsi tentang perubahan yang dilakukan),

2) Partisipasi (mengajak mereka yang berseberangan untuk berpartisipasi didalamnya),

3) Fasilitas dan dukungan (misalnya dengan memberikan motivasi dan reward),

4) Negoisasi (perundingan, musyawarah dengan pihak-pihak yang terkait) dan lain sebagainya.

${ }^{15}$ Ibid

${ }^{16}$ Stephen P. Robbins. 1999. Prinsip-prinsip Perilaku Organisasi. Alih Bahasa. Halida - Dewi Sartika. 2002. Jakarta;Erlangga, hlm. 302-310 
Diperoleh simpulan pengembangan organisasi PO/OD pada dasarnya mengarah pada adanya suatu perubahan dalam tubuh organisasi dalam rangka meningkatkan efektifitas dan efisiensi kerjanya, dengan tujuan untuk memperbaiki kemampuan organisasi dalam beradaptasi dengan perubahan lingkungan serta untuk merubah perilaku anggota organisasi.

\section{Pendekatan Kepemimpinan: Team Building}

Absennya kerja tim pada suatu tingkatan atau di antara tingkatan akan membatasi efektifitas organisasi dan akhirnya mematikan organisasi tersebut. Diperlukan usaha untuk membentuk dan memelihara kerja sama tim. Jika seorang pemimpin tidak mengutamakan kerja sama tim, maka efektivitas tidak akan terjadi. Kerja sama tim memerlukan usaha untuk mengembangkannya, dan upaya terus menerus untuk memeliharannya agar hasil yang di peroleh sebanding. ${ }^{17}$

Richard Denny ${ }^{18}$ mengemukakan pendapat bahwa Semua pemimpin dan motivator tim mengetahui tentang hukum motivasi yakni "ketika motivasi tercipta, ia tidak bersifat abadi", maka perlu diciptakan Iklim harus cocok. Prinsip ini, tentu saja diterapkan bukan hanya untuk memotivasi diri individu, tetapi juga untuk mengubah kelompok menjadi sebuah tim. Agar menjadi termotivasi dan bahagia didalam pekerjaan, ada lima prinsip yang dapat dilakukan yakni:

1. Mereka seharusnya mampu

2. Mereka harus sesuai untuk jabatannya

3. Mereka tidak boleh berpuas diri

4. Mereka harus merasakan sukses

5. Mereka harus mempunyai sikap yang tepat

Kompetisi merupakan hal yang sangat penting dalam kehidupan, karena kompetisi dapat menyingkap faktor-faktor yang menyebabkan kebinasaan, keterbelakangan dan kelemahan kemudian diantisipasi. Dengan adanya kompetisi juga akan tampak faktor-faktor penyebab pertumbuhan, kemajuan dan kekuatan. ${ }^{19}$ Akan tetapi adanya kompetisi baik antar anggota maupun antar organisasi perlu mendapat perhatian dari seorang pemimpin, karena jika tidak persaingan yang tidak sehat akan berkembang dan pada akhirnya kan merugikan organisasi itu

\footnotetext{
${ }^{17}$ Robert B. Maddux. Tanpa Tahun. Team Building: Terampil Membangun Tim Handal. Alih Bahasa Kristiyabudi P. Hananto. 2001. Jakarta;Erlangga. Edisi 2. hlm. 10-11

${ }^{18}$ Richard Denny. 1993. Sukses Memotivasi: Jurus Jitu Meningkatkan Prestasi. Terjemahan oleh Pius M. Sumaktoyo. 1997. Jakarta;Gramedia Pustaka Utama. Cet. Keempat.hlm. 79-81

${ }^{19}$ Ali Muhammad Taufiq. Praktik Manajemen Berbasis Al Qur'an. Jakarta: Gema Insani Press. Hlm. 37-41
} 
sendiri. Dalam hal ini seorang pemimpin dituntut untuk memiliki kemampun untuk menciptakan persaingan yang sehat agar menjadi pendorong untuk maju dengan tanpa mengabaikan pentingnya menjalin kerjasama. ${ }^{20}$

Ada beberapa faktor yang mendorong usaha pembentukan tim yang efektif, diantaranya ${ }^{21}$ :

1. Makin meningkatnya spesialisasi dalam organisasi. Makin kompleksnya suatu organisasi menunut makin besar dan tajamnya spesialisasi. Adanya spesialisasi ini bila tidak ditangani dengan baik akan dapat menimbulkan terjadinya cara bekerja kotak-kotak

2. Makin meningkatnya konsepsi partisipasi. Perkembangan teori dan praktek organisasi dan manajemen masa kini antara lain ditandai oleh makin berkembangnya pengakuan akan harkat dan martabat manusia. Hal ini membawa konsekuensi bahwa manusia tidak hanya diperlakukan sebagai salah satu unsur produksi. Mereka menuntut dan sudah diperlakukan untuk berperan serta dalam keseluruhan proses manajemen atau kegiatan organisasi.

3. Adanya konsepsi synergy. Sudah tidak dipersoalkan lagi bahwa apabila para anggota organisasi dapat berfikir, bertindak serta bekerja bersama, maka mereka akan dapat menghasilkan suatu yang sering diluar perkiraan orang lain. Hasil berbagai penelitian menunjukkan bahwa adanya kerjasama yang serius dapat mengembangkan kreatifitas, kemampuan memecahkan persoalan dan perasaan keikutsertaan yang lebih besar.

Selain itu ada Sepuluh kunci untuk menciptakan lingkungan yang sesuai bagi tim agar dapat termotivasi secara alamiah. Itu adalah salah satu prinsip besar dalam kepemimpinan yang baik dan bersifat memotivasi, yang tidak berupa sesuatu yang membebani atau memaksa melainkan berupa suatu iklim positif dan alami bagi ungkapan yang bersifat memotivasi sehingga kerja tim dapat lebih efektif ${ }^{22}$, 1) Kondisi kerja yang positif, 2) Budaya prioritas, 3) Sasaran umum, 4) Pertahankan energi tinggi, 5) Ingatlah akan individu, 6) Identitas tim, 7) Sukses harus dinikmati bersama-sama, 8) Tim yang Positif, 9) Kepemimpinan yang memotivasi.

Jika tim telah terbentuk dan dikembangkan dengan baik untuk sebagai salah satu upaya yang dilakukan dalam pengembangan organisasi, maka diperlukan adanya suatu tolok ukur yang

${ }^{20}$ Charles J. Keating. 1982. Kepemimpinan: Teori dan pengembangannya. Alih Bahasa oleh A.M. Mangunhadjana.2003. Yogyakarta;Kanisius. Cet. 15 hlm. 32-35

${ }^{21}$ Mas'ud Sa'id. 2006. Kepemimpinan: Pengembangan Organisasi, Eam Building dan Perilaku Inovative. Makalah disajikan dalam kuliah Kepemimpinan Pendidikan Islam UIN Malang. 29 Mei 2006. Lihat Adam I. Indrawijaya. Op.Cit. Hlm. 106-107

${ }^{22}$ Richard Denny. 1993. Op. Cit. .hlm. 81-87 
mencerminkan indikator efektifitas suatu tim. Menurut Adam I. Indrawijaya terdapat Beberapa Indikator yang menunjukkan Efektifitas Suatu Team, yakni: ${ }^{23}$

1. Rasa saling percaya

2. Adanya keinginan untuk saling membantu

3. Adanya komunikasi yang terbuka

4. Adanya tujuan bersama

5. Penyelesaian konflik secara terbuka

6. Pemanfaatan potensi sumber daya manusia yang optimal

7. Piranti pengawasan dilakukan secara bersama

8. Adanya iklim organisasi yang bebas dari intrik, terbuka dan sportif

\section{Individual Building: Perilaku Inovative}

Patricia Patton sebagaimana dikutip ఏohanes Papu menyebutkan bahwa It took a heart, soul and brains to lead a people..... ${ }^{24}$ dalam hal ini berarti seorang pemimpin dalam memimpin hendaknya tidak hanya melibatkan kecerdasan intelektual saja, melainkan juga memakai hati. Pernyataan sangat tepat karena dengan semakin banyak teknologi yang digunakan dalam organisasi terkadang membuat hubungan dalam organisasi berlangsung secara "kaku" dan kurang manusiawi, oleh sebab itu diperlukan pola hubungan yang lebih fleksibel yang pada akhirnya akan tercipta hubungan manusiawi dalam organisasi.

Jika seorang pemimpin telah mempu memposisikan diri sebagai seorang inovator maka ia dapat mengembangkan perilaku anggota organisasi, misalnya untuk pengembangan pribadi anggota dapat dilakukan dengan memberikan motivasi mereka, memberikan reward, memberi kesempatan kepada mereka melakukan sesuatu untuk organisasi, dan lain sebagainya yang kesemuanya akan bermuara pada kepercayaan diri, kebanggaan, kebahagiaan, yang pada akhirnya akan meningkatkan rasa ikut memiliki organisasi. Sedangkan untuk pengembangan pemimpin ia dapat menghasilka ide-ide, mengkombinasikan ide-ide lama dengan ide-ide baru atau mungkin dapat bertindak sebagai katalisator guna mengembangkan dan menerapkan inovasi-inovasi. ${ }^{25}$

\footnotetext{
${ }^{23}$ Adam I. Indrawijaya. 1989.Op. Cit. Hlm. 112-114

${ }^{24}$ http://72.14.203.104/search?q=cache:FndyoH-5wN8]:www.e-psikologi.com/wirausaha/eq.

${ }^{25}$ Winardi. 2000. Kepemimpinan dalam Manajemen. Jakarta;Rineka Cipta. Cet. 2. Edisi Baru hlm. 166-167
} 
Stephen P. Robbins mengemukakan beberapa hal yang perlu dipertimbangkan bagi seorang pemimpin dalam memilih suatu pendekatan yang disesuaikan dengan situasi dan tujuan yang dikehendaki, diantaranya adalah ${ }^{26}$ :

Pertama, Gunakan persaingan bila tindakan cepat dan tegas itu vital misalnya mengenai isu penting, dimana tindakan tidak popular perlu dilaksanakan; mengenai isu yang vital bagi kesejahteraan bila seorang pemimpin tahu bahwa ia benar; dan melawan orang-orang yang memanfaatkan perilaku tidak kompetitif.

Kedua, Gunakan kolaborasi untuk menemukan pemecahan integratif bila kedua perangkat kepentingan terlalu penting untuk dikompromiskan; bila sasaran anda adalah belajar; menyatukan wawasan-wawasan dari orang-orang dengan perspektif yang berlainan; untuk memperoleh komitmen dengan memasukkan kepentingan kedalam suatu consensus; dan untuk bekerja lewat perasaan yang telah mengganggu hubungan.

Ketiga, Gunakan penghindaran bila ada isu yang sepele, atau ada isu yang lebih penting yang mendesak bila anda mempersepsikan tidak adanya peluang bagi terpuaskannya kepentingan anda; bila gangguan potensial lebih dari mengimbangi manfaat suatu pemecahan; membiarkan orang-orang mendingin dan memperoleh kembali perspektif; bila pengumpulan informasi menggantikan keputusan yang segera; bila orang-orang lain dapat memecahkan konflik dengan lebih efektif; dan bila isu tampak menyinggung atau bersifat gejala dari isu-isu lain.

Kelima, Gunakan kompromis bila tujuan penting, tetapi tidak layak mendapatkan upaya pendekatan-pendekatan yang lebih tegas yang disertai kemungkinan gangguan; bila lawan dengan kekuasaan yang sama berkomitmen terhadap tujuan-tujuan yang secara timbal balik eksklusif (terhadap tujuan kita); untuk mencapai penyelesaian sementara terhadap isu yang rumit; untuk sampai pada pemecahan yang bijaksaana karena tekanan waktu dan sebagai suatu cadangan bila kolaborasi atau persaingan tidak berhasil. Perundingan ditunjukkan sebagai kegiatan yang terus menerus dalam kelompok dan organisasi.

\section{The Spiritual Leadership}

Untuk memperoleh ketenangan dan kedamaian manusia membutuhkan kecerdasan yang lain yang tertuju pada apa yang disebut oleh Ary Ginanjar dengan God Spot atau spiritual center

\footnotetext{
${ }^{26}$ Stephen P. Robbins. 1996. Perilaku Organisasi: Konsep, Kontroversi, Aplikasi. Alih Bahasa oleh Hadyana Pujaatmaka. Jakarta; Prenhalindo. Hlm 151-152
} 
secara transendental. ${ }^{27}$ Menurut Zohar dan Marshal sebagaimana dikutip oleh Tobroni ${ }^{28}$, SQ merupakan pondasi yang diperlukan bagi keefektifan dua kecerdasan yang lain," SQ is the necessary foundation for the functioning of both IQ and EQ.it is our ultimate intelligence".

Seorang pemimpin merupakan agen perubahan yang terpenting, maka salah satu upaya yang dapat dilakukan dalam pengembangan individu seorang pemimpin diantaranya adalah dengan menerapkan Kepemimpinan Spiritual (The Spiritual Leadership). Kepemimipinan spiritual bisa diartikan sebagai kepemimpinan yang sangat menjaga nilai-nilai etis dan menjunjung tinggi nilai-nilai spiritual. Mereka melakukan pekerjaan dengan cara memuaskan hati lewat pemberdayaan, memulihkan dan menguntungkan siapa saja yang berhubungan dengannya. Mereka tidak hanya mampu memberikan keuntungan finansial saja, tetapi juga hati dan jiwa mereka dalan bekerja. Mereka terlibat sepenuhnya (involve) dalam aktifitas organisasi yang dipimpinnya sebagai bentuk komitmennya yang paling dalam yaitu komitmen spiritualitas. Menurut Percy sebagaimana dikutip oleh Tobroni dalam hal ini mengatakan ${ }^{29}$;

"Dan ketika anda bermukim di rumah spiritualitas, tidak ada lagi jurang menganga dan daerah perbatasan antara keyakinan dan tindakan. Jurang itu diisi dengan esensi dan selaku manusia yang utuh. Anda dan obyek komitmen anda telah menyatu sempurna".

Dalam memimpin sebuah organisasi, seorang pemimpin tidak dapat hanya dengan mengandalkan atau memperhatikan satu aspek dari ketiga macam potensi yang ia miliki dan yang dimiliki oleh anggota organisasi yang lain. Hal ini menimbulkan munculnya perilaku yang baik dan akan mampu memotivasi anggota organisasi kearah yang efektifitas dan efisiensi organisasi.

Sedangkan Tobroni mengemukakan karakteristik kepemimpinan spiritual yang berbasis etika religius diantaranya adalah Kejujuran sejati, fairness pengenalan diri sendiri, fokus pada amal sholeh, spiritulisme yang tidak dogmatis, bekerja lebih efisien, membangkitkan yang terbaik dalam diri sendiridan orang lain keterbukaan menerima perubahan, visionar tetapi fokus pada persoalan didepan mata, doing the right thing, disiplin tetapi tetap fleksibel, santai dan cerdas, dan kerendahan hati. ${ }^{30}$

\footnotetext{
${ }^{27}$ Ary Ginanjar Agustian. 2001. Rahasia Sukses Membangun Kecerdasan Emosi dan Spiritual ESQ (Emotional Spiritual Quotient) berdasarkan 6 Rukun Iman dan 5 Rukun Islam. Jakarta; Arga Wijaya Persada. Hlm xxxix.

${ }^{28}$ Tobroni. 2005. The Spiritual Leadership Pengefektifan Organisasi Noble Industry Melalui Prinsip-prinsip Spiritual Etis. Malang;UMM Press. Hlm 21

${ }^{29}$ Ibid.

${ }^{30}$ Ibid Hlm 26
} 
Pendekatan kepemimpinan spiritual ini sebenarnya merupakan implikasi dari kepemimpinan dalam Islam. Artinya Islam sebagai sebuah agama yang mengatur segala urusan ummatnya, telah memberikan aturan yang jelas dalam sumber ajarannya yakni Al Qur'an. Dalam Al Qur'an dikemukakan beberapa sifat yang harus dimiliki oleh seorang pemimpin sebagaimana diungkapkan Senada dengan hal tersebut Jawahir Tanthowi ${ }^{31}$ mengemukakan beberapa klarakteristik pemimpin yakni:

1. Berpengetahuan luas, kreatif, inisiatif, peka lapang dada dan selalu tanggap.(QS.Al Mujadalah:11)

2. Bertindak adil,jujur dan konsekwen.(QS Annisa':58)

3. Bertanggung jawab.(QS Al An'am:164)

4. Selektif terhadap informasi.(QS Al hujarat:6)

5. Memberikan peringatan.(QS Az zariat:55)

6. Memberikan petunjuk dan pengarahan.(QS As sajadah:24)

Secara lebih rinci sifat-sifat yang harus dimiliki oleh seorang pemimpin menurut Ali Muhammad Taufiq ${ }^{32}$, diantaranya adalah: memiliki pengetahuan dan kemampuan yang cukup untuk mengendalikan organisasinya (QS. Al Mulk: 1), Mempunyai keistimewaan yang lebih dibanding dengan orang lain (QS. Al Baqarah: 247), Memahami kebiasaan dan bahasa orang yang menjadi tanggung jawabnya. (QS. Ibrahim: 4), Mempunyai kharisma dan wibawa dihadapan manusia (QS. Huud: 91), konsekwen dengan kebenaran dan tidak mengikuti hawa nafsu (QS. Ash Shaad: 26), bermu'amalah dengan lembut dan kasih sayang terhadap yang dipimpinnya, agar orang yang dipimpin simpatik kepadanya (Ali Imran: 159), menyukai sausana saling mema'afkan antara pemimpin dan pengikutnya, serta membantu mereka agar terlepas dari kesalahan (QS. Ali Imran: 159), Bermusyawarah dengan para pengikutnya serta meminta pendapat dan pengalaman mereka (QS. Ali Imran: 159), Menertibkan semua urusan dan membulatkan tekad kemudian bertawakkal (menyerahkan urusan kepada Allah) (Ali Imran: 159), Membangun kesadaran akan adanya muraqabah (pengawasan dari Allah) sehingga terbina sikap ikhlas dimanapun, walaupun tidak ada yang mengawasinya kecuali Allah (QS. Al Hajj: 41), Memberikan Takaful Ijtima'I (Santunan Sosial) kepada para anggota, sehingga tidak terjadi kesenjangan sosial yang menimbulkanrasa dengki dan perbedaan strata sosial yang dapat merugikan organisasi (QS. Al Hajj: 41), Mempunyai pengaruh (power) yang dapat memerintah dan mencegah anggotanya untuk

\footnotetext{
${ }^{31}$ Jawahir Tanthowi. 1983. Unsur-Unsur Manajemen menurut Ajaran al Qur'an. Jakarta;Pustaka Al Husna. Hlm. 6o-63

${ }^{32}$ Ali Muhammad Taufiq. Op. Cit. Hlm. 37-41
} 
melakukan atau tidak melakukan sesuatu (QS. Al Hajj: 41), Tidak membuat kerusakan dibumi, tidak merusak hubungan sosial (QS. Al Baqarah: 205), bersedia mendengar nasihat dan tidak sombong, sekalipun nasihat itu berasal dari bawahannya (QS. Al Baqarah: 206).

Berikut disampaikan Perbadingan antara kepemimpinan spiritual dengan model kepemimpinan yang lain menurut Tobroni yakni: ${ }^{33}$

\begin{tabular}{|c|c|c|c|}
\hline Uraian & $\begin{array}{c}\text { Kepemimpinan } \\
\text { Transaksional }\end{array}$ & $\begin{array}{l}\text { Kepemimpinnan } \\
\text { Transformasional }\end{array}$ & $\begin{array}{c}\text { Kepemimpinan } \\
\text { Spriritual }\end{array}$ \\
\hline $\begin{array}{l}\text { Hakekat } \\
\text { kepemimpinan }\end{array}$ & $\begin{array}{l}\text { Fasilitas, kepercayaan } \\
\text { manusia (bawahan) }\end{array}$ & $\begin{array}{l}\text { Amanat dari sesama } \\
\text { manusia }\end{array}$ & $\begin{array}{l}\text { Ujian, amanat dari } \\
\text { Tuhan dan manusia }\end{array}$ \\
\hline $\begin{array}{l}\text { Fungsi } \\
\text { kepemimpinan }\end{array}$ & $\begin{array}{l}\text { Untuk membesarkan } \\
\text { diri dan kelompoknya } \\
\text { atas biaya orang lain } \\
\text { melalui kekuasaannya }\end{array}$ & $\begin{array}{l}\text { Untuk } \\
\text { memberdayakan } \\
\text { pengikut dengan } \\
\text { kekuasaan keahlian } \\
\text { dan keteladanan }\end{array}$ & $\begin{array}{l}\text { Untuk } \\
\text { memberdayakan dan } \\
\text { mencerahkan iman } \\
\text { dan hati nurani } \\
\text { pengikutnya melalui } \\
\text { jihad (pengorbanan) } \\
\text { dan amal shaleh } \\
\text { (altruistik) }\end{array}$ \\
\hline $\begin{array}{l}\text { Etos } \\
\text { kepemimpinan }\end{array}$ & $\begin{array}{l}\text { Mendedikasikan } \\
\text { usahanya kepada } \\
\text { manusia untuk } \\
\text { memperoleh imbalan } \\
\text { / posisi yang lebih }\end{array}$ & $\begin{array}{l}\text { Mendedikasikan } \\
\text { usahanya kepada } \\
\text { sesame untuk } \\
\text { kehidupan bersama } \\
\text { yang lebih baik }\end{array}$ & $\begin{array}{l}\text { Mendedikasikan } \\
\text { usahanya kepada } \\
\text { Allah dan sesama } \\
\text { manusia (ibadah) } \\
\text { tanpa pamrih apapun }\end{array}$ \\
\hline $\begin{array}{l}\text { Sasaran } \\
\text { tindakan } \\
\text { kepemimpinan }\end{array}$ & $\begin{array}{l}\text { Pikiran dan tindakan } \\
\text { yang kasat mata }\end{array}$ & $\begin{array}{l}\text { Pikiran dan hati } \\
\text { nurani }\end{array}$ & $\begin{array}{l}\text { Spiritualitas dan hati } \\
\text { nurani }\end{array}$ \\
\hline $\begin{array}{l}\text { Pendekatan } \\
\text { kepemimpinan }\end{array}$ & Posisi dan kekuasaan & $\begin{array}{l}\text { Kekuasaan, keahlian } \\
\text { dan keteladanan }\end{array}$ & $\begin{array}{l}\text { Hati nurani dan } \\
\text { keteladanan }\end{array}$ \\
\hline $\begin{array}{l}\text { Dalam } \\
\text { mempengaruhi } \\
\text { yang dipimpin }\end{array}$ & $\begin{array}{l}\text { Kekuasaan, perintah, } \\
\text { uang, sistem, } \\
\text { mengembangkan }\end{array}$ & $\begin{array}{l}\text { Kekuasaan, keahlian } \\
\text { dan kekuasaan } \\
\text { referensi }\end{array}$ & $\begin{array}{l}\text { Keteladanan, } \\
\text { mengilhami, } \\
\text { membangkitkan, }\end{array}$ \\
\hline
\end{tabular}

33 Tobroni. Op. Cit Hlm. 41 


\begin{tabular}{|l|l|l|l|}
\hline & interest, transaksional & & $\begin{array}{l}\text { memberdayakan, } \\
\text { memanusiakan }\end{array}$ \\
\hline $\begin{array}{l}\text { Cara } \\
\text { mempengaruhi }\end{array}$ & $\begin{array}{l}\text { Menaklukkan jiwa } \\
\text { dan membangun } \\
\text { kewibawaan melalui } \\
\text { kekuasaan }\end{array}$ & $\begin{array}{l}\text { Memenangkan jiwa } \\
\text { dan membangun } \\
\text { kharisma }\end{array}$ & $\begin{array}{l}\text { Memenangkan jiwa, } \\
\text { membangkitkan iman }\end{array}$ \\
\hline $\begin{array}{l}\text { Target } \\
\text { kepemimpinan }\end{array}$ & $\begin{array}{l}\text { Membangun jaringan } \\
\text { kekuasaan }\end{array}$ & $\begin{array}{l}\text { Membangun } \\
\text { kebersamaan }\end{array}$ & $\begin{array}{l}\text { Membangun kasih, } \\
\text { menebar kebajikan } \\
\text { dan penyalur rahmat } \\
\text { Tuhan. }\end{array}$ \\
\hline
\end{tabular}

Dalam aplikasinya kepemimpinan spiritual ini akan memunculkan beberapa perilaku yang berbeda dengan kepemimpinan yang lain karena kepemimpinan dalam hal ini bukan hanya dipandang sebagai urusan terkait memimpin dengan menggunakan seluruh potensi kecerdasan, memimpin dengan ruh, memimpin dengan hati, memimpin dengan hati terbuka melainkan juga terkait dengan urusan dengan Tuhan SWT.

\section{Kesimpulan}

Organisasi senantiasa mengalami perubahan karena faktor pendorong baik yang berasal dari dalam organisai maupun luar organisasi. Saat ini, agar suatu organisasi mampu bertahan tidak cukup hanya mengandalkan kharisma seorang pemimpin, maka diperlukan pula kecerdasan dari seorang pemimpin untuk merespon berbagai perubahan yang terjadi disekitarnya serta melakukan berbagai macam inovasi, baik itu melaui Organizational Development (OD), Team Building maupun Pengembangan Individu untuk membentuk perilaku innovative.

Dalam diri manusia terdapat kecerdasan spiritual (spiritual quotient SQ), sebagai salah satu model kepemimpinan yang perlu diadopsi dan mendapat tanggapan dari seorang pemimpin yakni model kepemimpinan spiritual.

Dalam melakukan pengembangan organisasi hendaknya memperhatikan faktor-faktor yang lain, diantaranya faktor komunikasi baik tentang program, proses maupun monitoring dan evaluasi), sosiologis, psikologis dan historis yang melingkupi organisasi sehingga pada saat seorang pemimpin melakukan perubahan tidak akan terjadi gejolak yang besar diantara para anggota organisasi. 


\section{Daftar Pustaka}

Adzim, Ali Abdul. 1989. Falsafah Al Ma'rifat Fil Qur'an Al Karim. (terj). Kalilullah Ahmad Masykur Hakim. Epistemologi dan Aksiologi Ilmu Perspektif Al Qur'an. Bandung; CV. Rosda.

Agustian, Ary Ginanjar. 2001. Rahasia Sukses Membangun Kecerdasan Emosi dan Spiritual ESQ (Emotional Spiritual Quotient) berdasarkan 6 Rukun Iman dan 5 Rukun Islam. Jakarta; Arga Wijaya Persada.

Crow, Lester. D - Alice Crow. Educational Psychology. (terj). Z. Kasijan. 1984. Psikologi Pendidikan. Surabaya; Bina Ilmu.

Davis, Keith. 1985. Human Behavoir at Work: Organizational Behavior, Seventh Edition. Alih bahasa oleh Agus dharma. 2004. Jakarta;Erlangga. Cet. 12

Denny, Richard. 1993. Sukses Memotivasi: Jurus Jitu Meningkatkan Prestasi. Terjemahan oleh Pius M. Sumaktoyo. 1997. Jakarta; Gramedia Pustaka Utama. Cet. Keempat.

Goleman, Daniel. Emotional Intelligence. (terj) Hermaya. 1999. Jakarta; Gramedia Pustaka Utama.

http://72.14.203.104/search?q=cache:FndyoH-5wN8J:www.e-psikologi.com/wirausaha/eq.

Hughes, Ginnet and Curphy. 2002. Leadership; Enhancing The Lesson of Experience 4thEd. McGraw Hill Irwin.

Indrawijaya, Adam I. 1989. Perubahan dan Pengembangan Organisasi, Bandung; Penerbit Sinar Baru.

J.P, Chaplin. 2002. Kamus Lengkap Psikologi (terj). Kartini kartono. Jakarta; PT RajaGrafindo Persada. Ed. 1 Cet. 8

Kartono, Kartini. 2004. Pemimpin dan Kepemimpinan, Apakah Pemimpin Abnormal itu?. Jakarta; RajaGrafindo Persada. Cet. 12

Keating, Charles J. 1982. Kepemimpinan: Teori dan pengembangannya. Alih Bahasa oleh A.M. Mangunhadjana.2003. Yogyakarta; Kanisius. Cet. 15

Maddux, Robert B. Tanpa Tahun. Team Building: Terampil Membangun Tim Handal. Alih Bahasa Kristiyabudi P. Hananto. 2001. Jakarta; Erlangga. Edisi 2.

Mohyi, Ach.1999. Teori dan perilaku Organisasi. Trioningsih -Ratih Juliati (ed). Malang; UMM.

Nawawi, Hadari. 2003. Kepemimpinan Mengefektifkan Organisasi. Yogyakarta; Gadjah Mada University Press. 
Pertiwi, Aprilia Fajar, dkk. 1997. Mengembangkan Kecerdasan emosi. Sei Ayahbunda. Jakarta; Yayasan aspirasi Pemuda.

Robbins, Stephen P. 1996. Perilaku Organisasi:Konsep, Kontroversi, Aplikasi. Alih Bahasa oleh Hadyana Pujaatmaka. Jakarta; Prenhalindo.

. 1999. Prinsip-prinsip Perilaku Organisasi. Alih Bahasa. Halida - Dewi Sartika. 2002. Jakarta; Erlangga.

Sa'id, Mas'ud. 2006. Kepemimpinan: Pengembangan Organisasi, Eam Building dan Perilaku Inovative. Makalah disajikan dalam kuliah Kepemimpinan Pendidikan Islam UIN Malang. 29 Mei 2006.

Saleh, Abdul Rahman-Muhbib Abdul wahab. 2004. Psikologi (Suatu Pengantar Dalam Perspektif Islam). Jakarta; Kencana.

Satiadarma, Monty. P - Fedelis E. Waruwu. 2003. Mendidik Kecerdasan (Pedoman Bagi Orang Tua dan Guru dalam Mendidik Anak Cerdas). Jakarta; Pustaka Populer Obor.

Siagian, Sondang P. 1987. Teknik Menumbuhkan Dan Mengembangkan Perilaku Organisasional. Jakarta; CV Haji Masagung. Cet. 1

Stoner, James A. F -R. Edward Freeman-Daniel R. Gilbert, Jr. 1995. Manajemen. Terjemahan oleh Alexander Sindoro. Jakarta; Prenhalindo 1996.

Strauss, George dan Leonard R. Sayles. 1980. Manajemen Personalia-Segi Manusia dalam Organisasi. Alih Bahasa Oleh Grace M Hadikusuma-Rochmulyati Hamzah. 1991. Jakarta; Gramedia. Cet. 2 edisi Revisi.

Tanthowi, Jawahir. 1983. Unsur-Unsur Manajemen menurut AjaranAal Qur'an. Jakarta; Pustaka Al Husna.

Taufiq, Ali Muhammad. Praktik Manajemen Berbasis Al Qur'an. Jakarta: Gema Insani Press.

Tim Penyusun Kamus Pusat Bahasa. 2001. Kamus Besar Bahasa Indonesia. Edisi 3. Jakarta; Balai Pustaka. Cet 1

Tobroni. 2005. The Spiritual Leadership Pengefektifan Organisasi Noble Industry Melalui Prinsipprinsip Spiritual Etis. Malang; UMM Press.

Usman, Husaini. 2004. Manajemen Pendidikan. Yogyakarta; Universitas Negeri Yogyakarta.

Winardi. 2000. Kepemimpinan dalam Manajemen. Jakarta; Rineka Cipta. Cet. 2. Edisi Baru

Wisnu Ur, Dicky -Siti Nurhasanah. 2005. Teori Organisasi, Struktur dan Desain . Malang; UMM Press. Cetakan kedua.

www.depdiknas.go.id/Jurnal/41 Subijanto.htm-83k 